\title{
An assessment of the impact of Koshi floods to birds and mammals
}

\author{
Hem Sagar Baral \\ Himalayan Nature, PO Box 10918, Kathmandu, Nepal \\ E-mail: hem.baral@gmail.com
}

\begin{abstract}
Flood impact assessment with a focus on wetland dependent birds and mammals was carried out in 2009. Data compared to 2008, showed decline in the total number of birds. The results showed that while some bird benefitted from replenished fish stock, many others suffered. South Asian River Dolphin Platanista gangetica increased in number within the Koshi Tappu Wildlife Reserve after the flooding. Poverty and illiteracy contributing to lack of awareness amongst local people were hampering conservation works in the Reserve.
\end{abstract}

Key words: Koshi Tappu, waterbirds, floods, impact

\section{Introduction}

Koshi Tappu Wildlife Reserve $\left(26^{\circ} 35^{\prime} \mathrm{N}-87^{\circ} 05^{\prime} \mathrm{E}\right)$ occupies 17,500 ha of the Sapta Koshi River floodplain at the most north-easterly extension of the Gangetic Plain. It ranges in altitude from $75-81 \mathrm{~m}$. The reserve is located between two flood control embankments and is subject to annual flooding. Approximately $70 \%$ of the reserve's land area is covered by grasslands (Heinen, 1993) although during high flood years a large area of grassland is destroyed and replaced by new alluvial deposits. Typha and Saccharum are major grassland species found here, although patches of Imperata and Phragmites are often seen (Peet et al., 1999). Medium size phantas interspersed with young Acacia trees are found in sandy islands. Riverine vegetation with Acacia catechu/Dalbergia sissoo forest dominates on the islands and edges of the reserve. Mostly young trees grow inside and on the edges of the reserve within embankments, the old mature trees being swept away by annual floods.

South of Koshi Tappu Wildlife Reserve lies the Koshi Barrage area. The area is $7 \mathrm{~km}$ from north to south and nearly $5 \mathrm{~km}$ breadth from east to west. More than $50 \%$ of the land area of the barrage is covered by water, and the remaining land area is subject to intensive agriculture. The barrage gates are regulated by the Indian Government according to a 99 year lease agreement between Nepal and India.

A large number of bird species (485) has been recorded in the Koshi Tappu and Barrage area (Baral, 2005). Koshi is by far the most important wetland staging post for migrating waders and waterfowl in Nepal (Inskipp \& Inskipp, 1991) and have been considered one of the most important in Asia (Scott, 1989). Koshi Tappu also has the largest heronry in Nepal where as many as 25,730 nests belonging to 12 species of medium to large waders have been reported in 1996 (Choudhary, 1996).

As many as 20 globally threatened bird species have been recorded in the Koshi Tappu and Koshi Barrage area and eleven of these occur regularly. This area is an Important Bird Area especially for some wetland and grassland species, notably Swamp Francolin Francolinus 
gularis, Lesser Adjutant Leptoptilos javanicus, and Bristled Grassbird Chaetornis striatus (Baral \& Inskipp, 2005). It holds the largest population of the globally threatened Swamp Francolin in Nepal (Baral, 1998; Dahal et al., 2007), and also supports a good population of the Bristled Grassbird (Baral \& Inskipp, 2005). The site is also important for Nepal's nearthreatened birds; 13 of the country's total of 23 occur and eight of these are wetland birds (Baral \& Inskipp, 2005). Only two restricted-range species have been recorded and both are rare visitors. Besides these, a number of nationally threatened species of birds occur in Koshi area (BCN \& DNPWC, 2011).

The reserve contains Nepal's last population of Asian Buffalo Bubalus bubalis arnee, a globally threatened species (IUCN, 2012). Other globally threatened species include South Asian River Dolphin Platanista gangetica, Hog Deer Axis porcinus, Smooth-coated Otter Lutrogale perspicillata, Gharial Gavialis gangeticus and Mugger Crocodile Crocodylus palustris (Baral \& Inskipp, 2005; IUCN, 2012).

Koshi dyke was breached on 18 August, 2008. This resulted in a big hue and cry not only because of the loss of lives and property of people living adjacent to the reserve but also due to impact of Koshi flood to wildlife. Koshi has been an important staging point for migratory birds (Inskipp \& Inskipp, 1991), therefore the Wetland and Wildfowl Trust conducted a proper study to assess the condition of wildlife in the aftermath of the floods.

\section{Methods}

Waterbird count was done following the standard protocol set by the Wetlands International for years 2008 and 2009. Data for both years were collected between 17 to 21 January to make the results comparable between years. The count in 2009 was especially targeted to see short-term changes in bird composition and their numbers after the dyke was breached. South Asian River Dolphins were recorded using direct observation and count method.

\section{Results}

In the year 2008, a total of 66 species and in the year 2009 a total of 72 species of water dependent birds were recorded from the study area. The total bird population in 2008 was 8550 whereas only 5485 were counted in 2009 indicating a decline of 3000 birds after the floods.

Following bird species were seen in higher numbers in 2009 count; Great Cormorant Phalacrocorax carbo, Oriental Darter Anhinga melanogaster, Pallas' Gull Larus ichthyaetus, Heuglin's Gull L. heuglini, Black-bellied Tern Sterna acuticauda, Small Pratincole Glareola lactea, Grey Heron Ardea cinerea, Great Egret Casemrodius albus and Goosander Mergus merganser. But the following species declined in numbers: Ruddy Shelduck Tadorna ferruginea, Lesser Whistling Duck Dendrocygna javanica, Cattle Egret Bubulcus ibis, Northern Pintail Anas acuta, Asian Openbill Anastomus oscitans, Intermediate Egret Mesohoyx intermedia etc., and following species were not recorded: Pheasant-tailed Jacana Hydrophasianus chirurgus, Cotton Pygmy Goose Nettapus coromandelianus and Black-necked Stork Ephippiorhynchus asiaticus.

Up to eight South Asian River Dolphins were counted on the northern side of the barrage in Koshi Tappu Wildlife Reserve which in previous years were absent from the Reserve. Prior to the flooding, most dolphins were confined to southern side of the barrage. 


\section{Discussion}

A marked decline in wintering and passage migrant water bird has been noted since 1990 and has been highlighted through the data collected as part of the Annual Waterfowl Counts (BCN \& DNPWC, 2011). In February 2003 a total of nearly 9,800 birds were counted at the site in one day, a very low number compared to twenty years ago when more than 50,000 birds were estimated (Choudhary, 2003).

The overall impact of Koshi floods has been negative to wildlife including most birds. The number of congregatory birds has been drastically reduced largely because large bodies of still water for birds to rest have been significantly reduced. This combined with large amount of construction work to restore the breached dyke have put severe impacts on birdlife, especially water birds.

Many birds preferring shallow wetlands are totally absent e.g., Cotton Pygmy Goose and Pheasant-tailed Jacana. There are few others which found in lower numbers eg, Ferruginous Duck Aythya nyroca. As the flood destroyed much of the marshlands on the southeastern side of the Reserve, secretive species of crakes and snipes are also affected.

The flood however seems to have benefited a few species of birds e.g., Great Cormorant, Goosander, gulls and tern species as well as Great Egret and Grey Heron. Two Indian Cormorants Phalacrocorax fuscicollis were recorded during the winter after the flood; this species was new record for Nepal (Himalayan Nature Press Release, 2010). Increase in the number of fish eating birds and dolphins reflects more suitable habitat created for them as well replenished source of fish stock after the dyke was breached. Koshi Barrage has been a major barrier for several species of migrating fish, dolphins and several other aquatic fauna that need regular upstream-downstream migration

After the flood, varieties of wildlife suffered because of a yearlong construction work. The flood and work after the floods made large areas of the reserve accessible to locals that previously remained inaccessible and undisturbed. The report concludes that the flood destroyed some of the best wetlands/marshland habitats at Koshi that existed on the southeastern section of the Koshi Tappu within its buffer zone.

Koshi Tappu is protected as Nepal's first Ramsar Site for its importance for migrating wildfowl, and the remnant population of Asian Buffalo. Although protected in papers, the reserve faces severe problems from overfishing, illegal grazing by domestic animals, fodder collection, hunting, disturbance of nesting and feeding areas, poisoning that not only kills fish, but also birds that feed on fish and aquatic insects (Baral \& Inskipp, 2005). All these have resulted in the deterioration and loss of suitable habitats for birds and other wildlife. Removal of dead logs and debris deposited in the river from the Reserve is rampant and has a direct effect on fish population. Significant populations of cattle and buffalo are adding to the problem of illegal grazing. More than two thirds of the 100000 people residing in the periphery of the Reserve are very poor (CSUWN, 2009). Poverty and associated illiteracy have been major issues that are inviting problems for the Reserve.

There have been a few environmental education initiatives mainly carried out to date by the UNDP funded Participatory Conservation Programme and through Darwin Initiative, UK funding via the Wildfowl and Wetland Trust, UK and Bird Conservation Nepal (Thapa \& Dahal, 2008). Since 2009, conservation and sustainable use of wetlands in Nepal, a five year 
project initiative of the UNDP and Government of Nepal and Himalayan Nature are working towards minimizing some of the conservation issues Koshi is facing. There are also several other local NGOs helping to conserve biodiversity at Koshi Tappu. Despite these measurable benefits, conservation awareness amongst local people is low, majority of people are still poor and biodiversity conservation continues to be a major battle for the Reserve authority.

\section{Acknowledgements}

Author would like to thank Dr. Seb Buckton of the Wildfowl and Wetland Trust UK for supporting the midwinter waterbird count programme in Koshi area for the year 2009. Himalayan Nature and Koshi Camp provided additional support for which author is grateful to both institutions. Thanks are due to following participants of the waterbird counting programme without whom the work would have been impossible: Badri Chaudhary, Suchit Basnet, Bishnu Mahato, Som GC, Anish Timsina, Sanjib Acharya, Gauri Biswakarma, Rajji Uranwa, Tony Mainwood and Helen Mainwood.

\section{References}

Baral, H.S. \& C. Inskipp. 2005. Important Bird Areas in Nepal: key sites for conservation. Bird Conservation Nepal and BirdLife International, Kathmandu, Nepal and Cambridge, UK.

Baral, H.S. 1998. Status, distribution and habitat preferences of Swamp Francolin Francolinus gularis in Nepal. Ibisbill 1: 35-70.

Baral, H.S. 2005. Birds of Koshi. Department of National Parks and Wildlife Conservation and Bird Conservation Nepal. Kathmandu.

BCN \& DNPWC. 2011. The State of Nepal's Birds 2010. Bird Conservation Nepal and Department of National Parks and Wildlife Conservation: Kathmandu.

Chaudhary, H. 2003. One-day bird survey at Koshi Tappu Wildlife Reserve. Danphe 12(1/2): 6.

Choudhary, H. 1996. More news from the largest heronry of Nepal. Bird Conservation Nepal Newsletter 5(4): 3.

CSUWN. 2009. Baseline Survey Report, Koshi Tappu Wildlife Reserve (KTWR). Kathmandu, Nepal.

Dahal, B.R., P.J.K. McGowan \& S.J. Browne. 2007. Assessing the survival prospects of swamp francolin at Koshi Tappu Wildlife Reserve, southeastern Nepal. Annual Review of the World Pheasant Association 2006/2007: 28.

Heinen, J.T. 1993. Park-people relations in Koshi Tappu Wildlife Reserve: a socioeconomic analysis. Environmental Conservation 20(1): 25-34.

Himalayan Nature Press Release. 2010. Indian Shag Phalacrocorax fuscicollis: a new bird record for Nepal.

Inskipp, C. \& T. Inskipp. 1991. A guide to the birds of Nepal. Second edition. Christopher Helm, London, UK.

IUCN. 2012. IUCN Red List downloaded on 15 March 2009.

Peet, N., A.J. Watkinson, D.J. Bell \& B.J. Kattel. 1999. Plant diversity in the threatened subtropical grasslands of Nepal. Biological Conservation 88: 193-206.

Scott, D.A. (ed.) 1989. A directory of Asian wetlands. International Union for Conservation of Nature and Natural Resources. Gland, Switzerland and Cambridge, U.K.

Thapa, I. \& B.R. Dahal. 2008. Sustainable wetland management for wildlife and people at Koshi Tappu Wildlife Reserve. Banako Janakari Special issue. pp. 36-39. 